\title{
ULTRASTRUCTURAL CALLI ANALYSIS OF Inga vera WILLD. SUBSP. Affinis (DC.) T.D. PENN ${ }^{1}$
}

\author{
Vanessa Cristina Stein ${ }^{2}$, Renato Paiva ${ }^{3}$, Daiane Peixoto Vargas ${ }^{4}$, Fernanda Pereira Soares ${ }^{5}$, Eduardo \\ Alves $^{3}$ e Gabriela Ferreira Nogueira ${ }^{6}$
}

\begin{abstract}
Subcellular changes are relevant to understand plant organogenesis and embryogenesis in the early stages of cell development. The cytology during cell development in tissue culture is however still poorly characterized. This study aimed to characterize the ultrastructural differences related to callogenesis of anthers, ovaries, leaf and nodal segments of Inga vera Willd. subsp. Affinis (DC.) T.D. Penn. Flower buds, nodal segments and leaves were disinfected and inoculated in test tubes containing MS medium with $3 \%$ sucrose and $4.5 \mu \mathrm{M}$ 2.4-D, except for leaf callogenesis, where $9 \mu \mathrm{M}$ of this auxin was used, and for the callogenesis of anthers and ovaries, where the culture medium was enriched with $0.25 \%$ activated charcoal and 90 $\mu \mathrm{M}$ PVP. After 45 days in culture medium, the anther, ovary, leaf and nodal segment calli were fixed in Karnovisky and prepared for visualization by scanning and transmission electron microscopy. Ultrastructural differences were observed among the callus cells of anthers, ovaries, segments and leaves. There was no evidence of somatic embryo formation in the anther, leaf and nodal segment calli, in spite of some embryogenic characteristics in the cells. The ovary calli, with indications of embryo formation, seem to be the most responsive explant source for embryogenesis.

Keywords: Anthers, Ovaries e Nodal segments.
\end{abstract}

\section{ANÁLISE ULTRAESTRUTURAL DE CALOS DE INGAZEIRO (Inga vera WILLD. SUBSP. Affinis (DC.) T.D. Penn.)}

\begin{abstract}
Resumo - A compreensão da organogênese e embriogênese de plantas, nos estágios iniciais de desenvolvimento das células, requer a observação das mudanças subcelulares. No entanto, a caracterização citológica durante o desenvolvimento desses estágios não tem sido realizada com frequência na cultura de tecidos. Portanto, o objetivo deste trabalho foi caracterizar as diferenças ultraestruturais relacionadas a calogênese de anteras, ovários, folha e segmentos nodais de Inga vera Willd. subsp. Affinis (DC.) T.D. Penn. Para tanto, botões florais, segmentos nodais e folhas foram desinfestados e inoculados em tubos de ensaio contendo meio MS com 3\% de sacarose e 4,5 $\mu M$ de 2,4-D, exceto na calogênese de folhas, em que foram utilizados $9 \mu M$ dessa auxina, e na calogênese de anteras e ovários, cujo meio de cultura foi acrescido de 0,25\% de carvão ativado e 90 HM de PVP. Após 45 dias em meio de cultura, os calos de anteras, ovários, folhas e segmentos nodais foram fixados em Karnovisky e preparados para a visualização em microscopia eletrônica de varredura e microscopia eletrônica de transmissão. Assim, foram observadas diferenças ultraestruturais entre as células dos calos provenientes de anteras, ovários, segmentos e folhas. Os calos de anteras, folhas e segmentos nodais não apresentaram evidências de formação de embriões somáticos, apesar de suas células possuírem algumas características embriogênicas. No entanto, os calos de ovários parecem ser a fonte de explante mais responsiva à embriogênese, mostrando indícios de formação de embriões.
\end{abstract}

Palavras-chave: Anteras, Ovários e Segmentos foliares.

\footnotetext{
${ }^{1}$ Recebido em 19.08.2009 e aceito para publicação em 02.03.2010.

${ }^{2}$ Universidade Federal de Goiás, UFG, Brasil. E-mail: <vanessastein@ibest.com.br>.

${ }^{3}$ Universidade Federal de Lavras, UFLA, Brasil. E-mail: <renpaiva@ufla.br>.

${ }^{4}$ Pós-Doutorado em andamento pela UFLA, Brasil. E-mail: <dvbio@hotmail.com>.

${ }^{5}$ Fernanda Pereira Soares - Ministério da Agricultura, Pecuária e Abastecimento, MAPA, Brasil. E-mail: <fernandapereirasoares@yahoo.com.br>.

${ }^{6}$ Doutoranda do Programa de Pós-Graduação em Ciência Florestal na Universidade Federal de Lavras, DBI - UFLA, Brasil. E-mail:<gabi_bioufla@hotmail.com>.
} 


\section{INTRODUCTION}

Inga vera Willd., of the family Fabaceae, is a medicinal species of fruit tree native to the Cerrado. The fruit pulp is white, slightly fibrous and rich in mineral salts (Lope, 2006). Some authors claim that the seed viability under natural conditions is extremely short, not longer than 15 days (Barbedo, 1998).

In this context, somatic embryogenesis is a feasible strategy to study the physiologic embryo development and for the large-scale production of synthetic seed. The technique is one of the best options for mass propagation of elite plants (Gupta et al., 1993), in view of the high multiplication rate, the possibility of production scaling, embryo maintenance in culture media, direct planting circumventing grafting, besides making gene transference possible, by protoplast fusion as well as by genetic transformation (Barros, 1999).

According to Ammirato (1983), in somatic embryogenesis a single cell or somatic cell group is precursor of somatic embryos, in a process that is similar to zygotic embryogenesis. Somatic embryos in vitro can be formed along the lines of two basic embryogenesis patterns, direct or indirect.

Direct somatic embryogenesis occurs based on the explant cells, which are programmed for the differentiation and somatic embryo formation. For indirect somatic embryogenesis, the de-differentiation of the explants results in the callus formation, with viable cells or cell groups, that is, with the capacity to respond to the stimulatory effects of the culture medium. By the transference of these now competent cells, to shoot-inducing media they become determined, that is, designated for a specific development route (Kerbauy, 1998).

According to Vikrant (2001), direct somatic embryogenesis occurs most frequently in microspore, ovule and immature embryo explants. Contrastingly, indirect somatic embryogenesis occurs in undetermined and non-differentiated cells, primarily in the calli.

Although the success of somatic embryogenesis in woody plants is insignificant, it was possible to work out somatic embryogenesis induction protocols for several forest species, including some members of the Lauraceae family, such as Laurus nobilis (Canhoto et al., 1999), Persea americana Mill. (Witjaksono et al., 1999) and Ocotea catharinensis (Viana and Mantell, 1999).

Pescador et al. (2000) reported that the possibility of manipulating in vitro systems for the cloning of superior plant genotypes depends on different factors, such as morphologic, genetic, biochemical and cytologic parameters as well as the understanding of the physiology of cell development, which is fundamental for morphogenetic responses in in vitro culture systems.

The reason why certain in vitro regenerative events are more easily induced in some tissues than in others is to date not satisfactorily elucidated, but it is admitted that the different morphogenetic expressions reflect the nature and degree of differentiation of these tissues.

The comprehension of plant organogenesis in the early development stages of the meristematic cells requires the study of the subcellular changes and correlations with biochemical alterations (PihakashiMaunsbach et al. 1993). The application of this methodology is promising to gain information associated to the morphologic and biochemical parameters of the viable cells (Santiago, 2003).

The embryogenic cells generally have characteristics in common with active embryogenic cells, including fast mitotic division, small size, dense cytoplasm, large nucleus with prominent nucleolus, small vacuole and abundance of starch grains. These characteristics suggest intense RNA synthesis and metabolic activity.

Some authors have tried to relate the ultrastructural characteristics to the embryogenic potential (Radojevic et al., 1975). However, the cytologic characterization during callus development is rather rare in tissue culture. There are few studies on the ultrastructural alterations during organogenesis in vitro to characterize meristem cells and shoot formation (Pihakashi-Maunsbach et al., 1993, Arai et al., 1997).

The lack of knowledge of somatic embryogenesis control factors and the asynchrony in the development of somatic embryos are the main reasons for the marginal commercial application (Pihakashi-Maunsbach, 1993). One of the strategies that could increase the efficiency of the embryogenic process is the ultrastructural analysis at the callus stages. 
This study aimed to characterize ultrastructural differences related to callogenesis of anthers, ovaries, leaf and nodal segments of Inga vera Willd. subsp. affinis (DC.) T.D. Penn.

\section{MATERIALAND METHODS}

\subsection{Plant material}

For the anther and ovary callogenesis, flower buds of Inga vera were collected from natural populations, on the campus of the Universidade Federal de Lavras, from August to November 2005 , and stored at $10^{\circ} \mathrm{C}$ for two days.

To induce calli in leaves and nodal segments, young inga mother plants were placed in a growth chamber at $25 \pm 2{ }^{\circ} \mathrm{C}$, photon flow density of $43 \mathrm{mmol} \mathrm{m}^{-2} \mathrm{~s}^{-1}$ and a 16 hour photoperiod. These plants were provided by the seedling nursery of the Centrais Elétricas of Minas Gerais (CEMIG), in the Camargos dam catchment area of Itutinga,

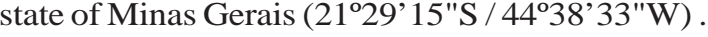

\subsection{Disinfection and inoculation of plant material}

Flower buds, nodal segments and leaves were washed in tap water for 20 minutes and immersed in a laminar flow chamber in $70 \%$ alcohol for 60 seconds and sodium hypochlorite with $2.5 \%$ active chlorine for 15 minutes. Then the specimens were washed three times in distilled, autoclaved water. Upon disinfection, the flower buds were cut longitudinally with a scalpel to separate the anthers or ovaries.

\subsection{Callogenesis}

The different explants were inoculated in test tubes containing MS medium (Murashige and Skoog, 1962), with $3 \%$ sucrose and $4.5 \mu \mathrm{M}$ 2.4-D (2.4dichlorophenoxyacetic acid), except for leaf callogenesis, where $9 \mu \mathrm{M}$ of this auxin was used and in the callogenesis of anthers and ovaries, where $0.25 \%$ activated charcoal and $0.9 \mathrm{mM}$ polyvinylpyrrolidone (PVP) was added to the culture medium.

All culture media were solidified with $0.7 \%$ agar and the $\mathrm{pH}$ adjusted to 5.8 , before autoclaving at $120^{\circ} \mathrm{C}$ for 20 minutes. The explants were kept in the dark at $27 \pm 2{ }^{\circ} \mathrm{C}$, for 45 days

\subsection{Transmission electron microscopy (TEM)}

After 45 days in culture medium, the anther, ovary, leaf and nodal segment calli were fixed in Karnovsky (2.5\% glutaraldehyde and $2.5 \%$ paraformaldehyde in calcodylate buffer, $\mathrm{pH} 7.0$ ) for 2 to 24 hours at room temperature.

The calli were washed in $0.05 \mathrm{M}$ calcodylate buffer (three times for 10 minutes) and post-fixed in 1\% osmium tetroxide and $0.05 \mathrm{M}$ calcodylate buffer for 4 hours.

The specimens were then dehydrated in an acetone gradient (30, 50, 70 and 90 for 10 minutes). The material was included in an increasing acetone gradient and $30 \%$ Spurr resin for 8 hours, 70\% resin for 12 hours and twice in $100 \%$ resin, in 24 hour intervals. The tissues were embedded in pure resin and heated to $70^{\circ} \mathrm{C}$, for 48 hours, for polymerization. Thereafter, semifine $(1 \mathrm{~mm})$ and ultra-fine $(<100 \mathrm{~nm})$ sections were cut with an ultramicrotome (Reichert-Jung). The semifine sections were stained with toluidine blue (1g toluidine blue, $1 \mathrm{~g}$ sodium borate and $100 \mathrm{~mL}$ of water filtered through $0.2 \mathrm{~mm}$ Millipore) and permanently mounted on Permoult medium.

The ultra-fine sections were collected in a drop of water with slot grids and placed in formvar-covered racks (Rowley \& Moran, 1975). The sections were postcontrasted in uranile acetate and lead acetate for 3 minutes each and finally examined under an electronic transmission microscope (Zeiss EM 109) at 80Kv.

\subsection{Scanning electron microscopy (SEM)}

After 45 days in culture medium,the anther, ovary,leaf and stem calli were fixed in Karnovsky (2.5\% glutaraldehyde and $2.5 \%$ paraformaldehyde) in calcodylate buffer, $\mathrm{pH}$ 7.0 , for at least one hour at room temperature.

Then the calli were cut with a bistoury in liquid nitrogen and the fragments washed three times (10 minutes) in $0.05 \mathrm{M}$ calcodylate buffer and postfixed in $1 \%$ osmium tetroxide and $0.05 \mathrm{M}$ cacodylate buffer for 1-2 hours. The specimens were dehydrated using an acetone gradient (30\%, 50\%, 70\% and $90 \%)$ for 10 minutes.

After dehydratation, the samples were dried to the critical point by liquid $\mathrm{CO}_{2}$, gold-coated, and analyzed by an electronic microscope (LEO Evo 40), operating at 10 and $20 \mathrm{kV}$.

Revista Árvore, Viçosa-MG, v.34, n.5, p.789-796, 2010 


\section{RESULTS}

Ultrastructural differences were observed among the callus cells of anthers, ovaries, segments and leaves (Figure 1). On callus anthers, cell proliferation of isodiametric shape was verified by SEM, on the entire anther surface (Figure 1a), including the connective tissue region and pollen grain (Figure 1b). The cell cytoplasm of the anther calli was dense and abundant in endoplasmic reticulum (Figure 2a), isodiametric mitochondria (Figure 2c and 2d) and also small vacuoles and starch grains (Figure 2b). Cells also showed a high nucleus:cytoplasm ratio showing a single prominent nuclei with stained nucleolus (Figure 1a).

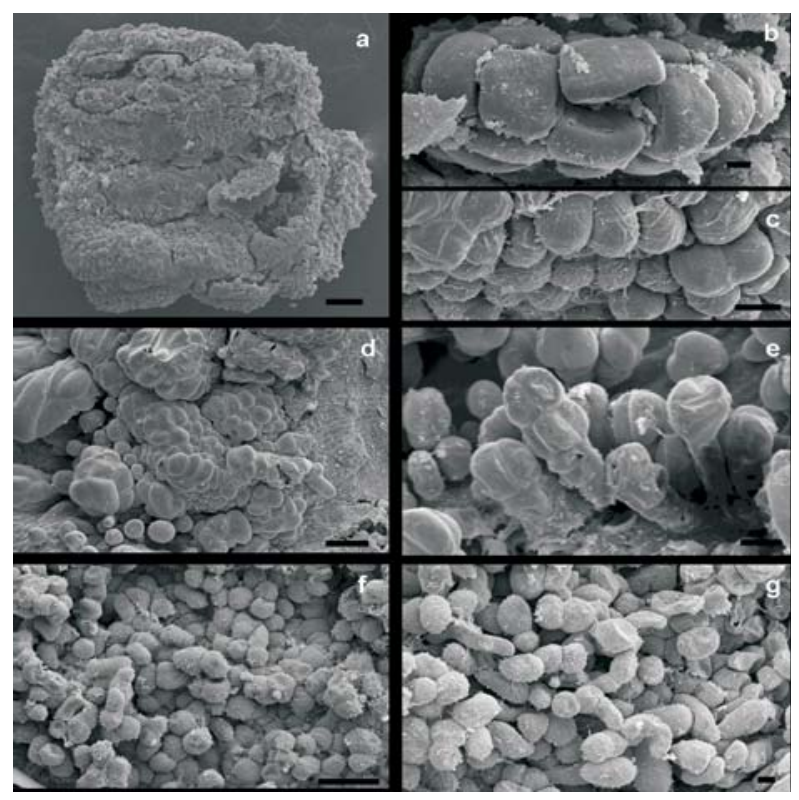

Figure 1 - Scanning electromicrographs of anther ovaries, segments and leaves calli of inga. Anther calli (a, b, c); General aspect of the anther calli (a); calli in the pollen (b); isodiametric callus cells (d). Ovary calli (d, e); beginning of embryo formation (d); torpedo-stage (e). Nodal segment calli aspects of the callus surface (f); Leaf calli aspects of the callus surface ( $\mathrm{g}$ ). $\mathrm{Br}=100 \mu \mathrm{m}$ (a); $10 \mu \mathrm{m}$ (b, d); $20 \mu \mathrm{m}$ (c, e, f, g).

Figura 1 -Eletromicrografias de varredura de calos em ovários, antera, segmentos nodais e folhas de ingá. Antera (a, b, c); Aspecto geral dos calos de anteras (a);calos no grão de pólen (b); células isodiamétricas dos calos (d). Calos no ovário $(d, e)$; início da formação do embrião (d); estádio torpedo (e). aspectos da superfície dos calos no segmento nodal ( $f$ ); aspectos da superfície do calos nas folhas $(\mathrm{g}) . \mathrm{Br}=100 \mu \mathrm{m}$ (a); $10 \mu \mathrm{m}(b, d), 20 \mu \mathrm{m}(c, e, f, g)$.

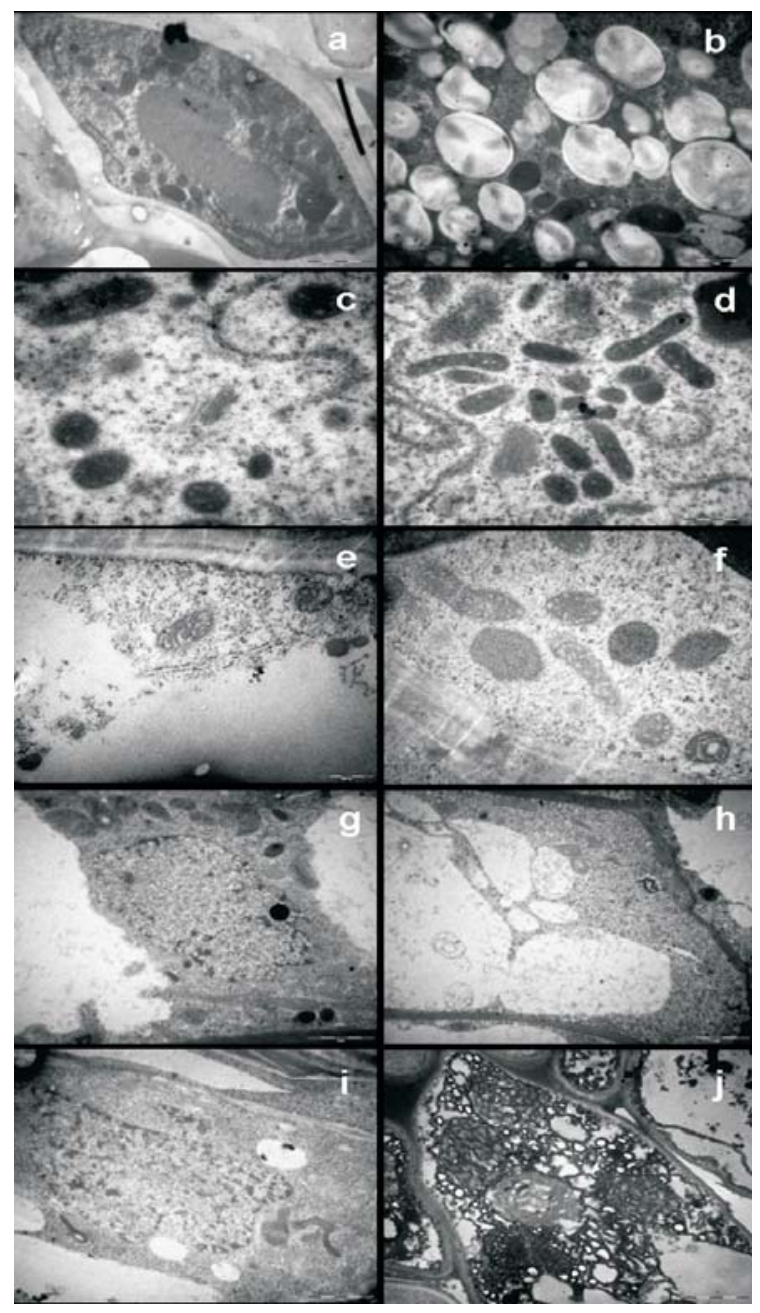

Figure 2-Transmission electromicrographs of anthers, ovaries, segments and leaves callus. Anther callus cell (a,b,c,d); starch grains (b); endoplasmic reticulum and Golgi complex (c); mitochondria (d). Ovary callus cells (e,f), peripheral cytoplasm with mitochondria and endoplasmic reticulum (e); mitochondria (f);. $\mathrm{Br}=500 \mu \mathrm{m}$ (a,b,c); $1 \mu \mathrm{m}$ (h). Nodal segment callus cells (g,h); nucleus (g); vacuole (h). Leaf calli (i,j); inviable cells (i,j). $\mathrm{Br}=20 \mu \mathrm{m}$ $\mathrm{Br}=2 \mu \mathrm{m}(\mathrm{a}, \mathrm{b}, \mathrm{c}, \mathrm{d}, \mathrm{g}, \mathrm{h}, \mathrm{i}, \mathrm{j}) ; \mathrm{Br}=500 \mu \mathrm{m}(\mathrm{e}, \mathrm{f})$.

Figura 2-Eletromicrografias de transmissão de calos em anteras, ovários, segmentos nodais e folhas. Calos nas anteras ( $a, b, c, d)$, das mitocôndrias (d), grãos de amido (b),retículo endoplasmático e complexo de Golgi (c).células do calo no ovário (e,f), citoplasma periférico commitocôndrias eretículo endoplasmático (e), mitocôndrias ( $f$ ); $\mathrm{Br}=500 \mu \mathrm{m}(a, b, c), 1 \mathrm{mM}$ (h). células dos calos do segmento nodal $(g, h)$; vacúolo (h); núcleo (g). calos da folha (i,j); células inviáveis $(i, j) . B r=20 \mu \mathrm{m} \mathrm{Br}=2 \mu \mathrm{m}(a, b, c, d$, $g, h, i, j) ; B r=500 \mu m(e, f)$. 
Cell proliferation on the surface of the ovary calli was well-organized and seems to be competent for somatic-proembryo formation observed by the cell division cluster and consequently development of somatic pro-embryos (Figure 1d). The presence of a torpedo stage (Figure 1f) with suspensor was also observed. In these cells the nuclei and organelles, such as mitochondria (Figure 2e) and endoplasmic reticulum, were observed in peripheral position, once the cell is practically totally occupied by large vacuoles. They can, however; be so covered in vacuoles that there is only a fine cytoplasm between the tonoplast and the plasmatic membrane (Figure 2e).

However, there were no indications of embryo formation on the callus surfaces of nodal segments and leaves. Most cells were round-shaped and some elongated (Figure 1f). Upon the cell analysis, cells with many vacuoles (Figure $2 \mathrm{~h}$ ), nuclei with different shapes and a large quantity of mitochondria (Figure 2g), mostly elongated, were observed. The leaf callus cell morphology was similar to that of the nodal segment cells, that is, rounded or elongeted (Figure $1 \mathrm{~g}$ ). The transmission analysis revealed many unviable cells (Figure $2 \mathrm{i}, \mathrm{j}$ ) while the few live cells had irregular nuclei; few organelles and amiloplasts were present A s mentioned above, the cells accumulate a large quantity of starch grains during the culture of somatic embryos, indicating that the starch grains can be used as initial embryogenic potential markers (Radojevic, 1979; Ho and Vasil, 1983). In this type of explant however, successive transfers for the selection of the live cells with embryogenic potential are necessary.

\section{DISCUSSION}

It is believed that calli have different abilities for somatic embryogenesis as their cells are in different conditions and have different characteristics (Pierik 1987). Embryogenic and non-embryogenic calli show differences, not only in morphological structures and embryogenesis behaviors, but also in their cellular features (Shang, et al., 2009).

Cells that formed embryogenic nodular structures contained dense cytoplasm and appeared to be similar to meristematic cells in isodiametric format (Shang, et al., 2009) as observed in cell cytoplasm of the Inga anther callus. This cell also has clusters of small vacuoles, starch grains, isodiametric mitochondria and Golgi complex described as characteristic of embryogenic calli (Bobák et. at., 2004). Ultrastructural changes of the cytoplasm associated with the individualization of embryogenic cells include the proliferation and activation of dictyosomes, with the formation of Golgi vesicles directly related to cell wall reorganization (Verdeil et al., 2001).

The presence of starch grains has been described as an ultrastructural change, common in organogenic cells and also related to the acquisition of the embryogenec capacity (Villalobos et al. 1985, PihakashiMaunsbach, et al 1993), and the consumption of these compounds has been correlated with the onset of organogenesis. Shang, et al., 2009 observed that the chloroplasts of embryogenic calli cells degenerated to proplastid-like structures with starch grain accumulation, and in contrast, chloroplasts of nonembryogenic calli cells showed a well organized thylakoid system. Starch is considerd to be the primary source of energy for cellular proliferation and growth (Cangahuala-Inocente et al.; 2004). These characteristics suggest that the anther calli have the potential to develop the somatic embryos necessary to stimulate these cells to follow the embryogenic pathway.

On the other hand, the ovary callus showed stages of the somatic embryogenisis. The small globular clusters of the cell without visible polarity were associated with early proembryos, whereas globular cluster with already established polarity were associated to later torpedo-like developmental stages, also suggested by Cangahuala-Inocente et al. (2004).

The formation of embryogenic protuberances on the ovary tissue probably was preceded by the accumulation of starch granules in the subepidermical cell layers of the explants, but the starch is rapidly consumed during the formation of embryogenic regions and is absent from globular and heart-shaped embryos (Rodrigo and Weizstein, 1998). On the ovary callus cells starch grains were not observed, indicating that the starch is rapidly metabolized in embryogenic tissues. Cangahuala-Inocente et al.; 2004 also did not observe starch grains on embriogenic tissue of Feijoa sellowiana.

The embryogenic ovary calli cells, the nuclei, and organelles such as mitochondria and endoplasmic reticulum, were observed in peripheral position once the cell is practically totally occupied by large vacuoles. As observed by Canhoto et al. (1996), the cells of the

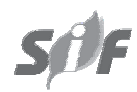

Revista Árvore, Viçosa-MG, v.34, n.5, p.789-796, 2010 
pro-embryos usually have some characteristics of the meristematic cells, however they can be so covered by vacuoles that there is only a fine cytoplasm between the tonoplast and the plasmatic membrane. The abundant presence of Mitochondria with electrodense matrix and well-developed crests and with round shape was observed in these cells and has also been associated to the embryogenic systems, related to the high metabolic activity due to high respiratory rates (Canhoto et al. 1996).

With regard to the analysis of leaves and nodal segments, the cells were round-shaped and some elongated, this is not desirable in embryogenic tissue, as reported by Shang, et al., the non-embryogenic callus varied greatly in shape, color and texture. On cytological analysis, the organelles and nucleus with different shapes were located in a narrow strip of cytoplasm between the cell wall and the large vacuole, which was located in the center as observed on no-embryogenic cotton cells (Shang, et al., 2009). The large quantity of mitochondria, mostly with an elongated shape, also indicated the non-embryogenic caracteristics. According to Canhoto (1996), non-embryogenic cells have longish mitochondria, while the mitochondria in embryogenic cells are rounded. However, Skoog and Miller (1957) affirmed that the non-embryogenic cells are able to develop meristematic cells and can, under satisfactory conditions, bring forth a new plant.

Probably the variation in morphogenetic structures of these different tissues is related to polar accumulation of an endogenous hormone which may produce the somatic embryos. This research showed the diverse morphogenetic potential of different primary explants of Inga, and the indirect influence of the explant type on regeneration abilities of cell cultures. Not all types of cells respond in the same way to the cultivate conditions and, for this reason, only some give the desired response in the culture. As pointed out by Carman (1990), embryogenic competence varies in different cells and may be related to gene activity that affects somatic embryogenesis, thus explaining why cells of the same explants possess different competence abilities.

\section{CONCLUSIONS}

There are ultrastructural differences between callus cells derived from anthers, ovaries, segments and leaves.
There was no evidence of somatic embryo formation in the calli of anthers, leaves and nodal segments, despite some embryogenic characteristics in the anther cells.

As explant source, the ovary calli were most responsive to embryogenesis, with indicationss of embryo formation.

\section{REFERENCES}

ASTARITA LV, GUERRA MP (1998). Early somatic embryogenesis in A. angustifolia-induction and maintenance of embryonal-suspensor mass cultures. Braz. J. Plant Physiol. v.10, p.113-118.

AMMIRATO, P. V. (1983). Embryogenesis. In: EVANS, D. A.; SHARP, W. R.; AMMIRATO, P. U.; YAMADA, Y. (Ed.). Handbook of plant cell culture. New York: Macmillan Publisher Company p. 82-123.

ARAI, M.; SAITO, T.; KANEKO, Y.; MATSUSHIMA, H. (1997). Cellular origin and ultrastructural changes of regenerating shoots from tobacco (Nicotiana tabacum) internodes cultured in vitro. Physiologia Plantarum, Copenhagen, v. 99, n. 4, p. 523-528, Apr.

BARBEDO, C. J.; CICERO, S. M. (1998). Utilização do teste de condutividade elétrica para previsão do potencial germinativo de sementes de ingazeiro. Scientia Agrícola, Piracicaba, v. 55, n. 2, p. 249-259, maio/ago.

BARROS, L. de M. (1999). Embriogênese somática. Biotecnologia Ciência e Desenvolvimento, Uberlandia, v. 2, n. 7, p. 36-43, jan./fev.

BOBÁK, M.; ŠAMAJ, J.; PRETOVÁ, A.; BLEHOVÁ, A.; HLINKOVÁ, E.; OVECKA, M.; HLAVACKAA.; AND KUTARNOVÁ, Z. (2004) The histological anal y sis of in di rect so matic embryogenesis on Drosera spathulata Labill. Acta Physiologiae Plantarum. v. 26. $\mathrm{n}^{\circ} 3$. p.353-361.

CANGAHUALA-INOCENTE, G. C.; STEINER, N.; MALDONADO, S.B.; GUERRA, M.P. Patterns of protein and carbohydrate accumulation during somatic embryogenesis of Acca sellowiana.

Pesq. agropec. bras., Brasília, v. 44, n. 3, Mar. 2009. 
CANHOTO, J. M.; LOPES, M. L.; CRUZ, G. S. (1999). Somatic embryogenesis in Bay Laurel (Laurus nobilis). In: JANI, S. M.; GUPTA, P. K.; NEWTON, R. J. (Ed.). Somatic embryogenesis in woody plants. Dordrecht: Kluwer Academic Publishers, 1999. v. 4, p. 341-367.

CANHOTO, J. M.; MESQUITA, J. F.; CRUZ, G. S. (1996). Ultrastructural changes in cotyledons of pineapple guava (Myrtaceae) during somatic embryogenesis. Annals of Botany, London, v. 78, n. 4, p. 513-521, Oct.

CARMAN, J.G. (1990). Embryogenic cells in plant tissue cultures : occurrence and behaviour. In Vitro Cellular and D.elopmental Biology v. 26, p.746 \pm 753 .

GLORIA, A. da B.; MACHADO, S. R. (2004).

Ultrastructural analysis of in vitro direct and indirect organogenesis. Revista Brasileira de

Botânica, São Paulo, v. 27, n. 3, p. 429-437, jul./sept.

GUPTA, P. K.; PULLMAN, G.; TIMMIS, R.; KREITINGER, M.; CARLSON, W. C.; GROB, J.; WELTY, E. (1993). Forestry in the 21st Century. Bio/ Technology, New York, v. 11, n. 4, p. 454-459, Apr.

HAI-HONG SHANG, CHUAN-LIANG LIU, CHAOJUN ZHANG, FENG-LIAN LI, WEI-DONG HONG AND FU-GUANG LI. Histological and Ultrastructural Observation Reveals Significant Cellular Differences between Agrobacterium Transformed Embryogenic and Non-embryogenic Calli of Cotton Journal of Integrative Plant Biology 2009, vol. 51 (5), p. 456-465.

HO, W.; VASIL, I. K. (1983). Somatic embryogenesis in sugarcane (Saccharum officinarum L.) I. The morphology and physiology of callus formation and the ontogeny of somatic embryos. Protoplasma, New York, v. 118, p. 169-180

KERBAUY, G. B. (1998) Competência e determinação celular em cultura de células e tecidos de plantas. In: TORRES, A. C.; CALDAS, L. S.; BUSCO, J. A. Cultura de tecidos e transformação genética de plantas. [S. 1. : s. n. ], v. 2, p. 569-612.

LOPE, K. P.; BRUNO, R. DE L. A.; BRUNO, G. B.; MOURA, M. F. (2006) Comportamento de sementes de Inga sp. durante o armazenamento. Disponível em: < http://www.ufpel.tche.br/ sbfruti/ anais_xvii_cbf/fitotecnia/355.htm>. Acesso em: $5 \mathrm{fev}$.
MURASHIGE, T.; SKOOG, F. A. (1962). A revised medium for rapid growth and biomass with tobacco tissue cultures. Physiologia Plantarum, Copenhagen, v. 15, n. 3, p. 473-92

PESCADOR, R.; ARAÚJO, P. S.; MAAS, C. H.; REBELO, R. A.; GIOTO, C. R.; WENDHAUSEN Jr., R.; LARGURA, G. TAVARES, L. B. B. (2000). Biotecnologia de Piper hispidinerviumpimenta longa.

Biotecnologia, Ciência e Desenvolvimento, Brasília, v. 3, n. 15, p. 19-23, jul./ago.

PIHAKASHI-MAUNSBACH, K.; NYGAARD, K. B.; JENSEN, K. H.; RASMUSSEN, O. (1993). Cellular changes in early development of regenerating thin cell layer-explants of rapeseed analysed by light and electron microscopy.

Physiologia Plantarum, Copenhagen, v. 87, n. 2, p. 167-176, Feb.

RADOJEVIC, L. (1979). Somatic embryos and plantlets from callus cultures of Paulownia tomentosa teud. Zeitschrif.t

Pflanzenphysiologie, Jena, v. 91, n. 1, p. 5762

RADOJEVIC, L.; VUJICIC, R.; NESKOVIC, M. (1975). Embryogenesis in tissue culture of Coryllus avellana L. Zeitschrift für. Pflanzenphysiologie, Jena, v. 77, p. 33-41

ROWLEY, C. R.; MORAN, D. T. (1975). A simple procedure for mounting wring wrinkle - free sections on formvar - coated slot grids. Ultramicrotomy, Amsterdam, v. 1, n. 1, p. 151-155

SANTIAGO, E. J. A de. (2003). Caracterização morfológica e bioquímica de calos de pimenta longa (Piper hispidinervium Candolle,

DeCandolle). 184 p. Tese (Doutorado em Fisiologia Vegetal) - Universidade Federal de Lavras, Lavras, MG.

SKOOG, F.; MILLER, C. O.(2000) Chemical regulation of growth and organ formation in plant tissue cultured in vitro. Symposium of Society for Experimental Biology, Cambridge, v. 11, p. 118-131.

TOMES, D. T. (1985). Cell culture, somatic embryogenesis and plant regeneration in maize, rice, sorghum and millets. In: BRIGHT, S. W.; JONES, M. G. K. (Ed.) Advances in agricultural biotechnology, cereal tissue and cell culture. Boston: Nijhoff/Junk. p. 175-203.

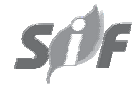

Revista Árvore, Viçosa-MG, v.34, n.5, p.789-796, 2010 
VIANA, A. M.; MANTELL, S. H. (1999). Somatic embryogenesis of Ocotea catharinensis: an endangered tree of the mata atlântica (South Brazil). In: JAIN, S. M.; GUPTA P. K.; NEWTON, R. J. Somatic embryogenesis in woody plants. Dordrecht: Kluwer Academic Publishers, 1999. v. 5, p. 3-30.

VIKRANT, A. R. (2001) Comparative study of somatic embryogenesis from immature and mature embryos and organogenesis from leafbase of Triticale. Plant Cell, Tissue and Organ Culture, Dordrecht, v. 64, n. 1, p 33-38, 2001.
VILLALOBOS, V. M.; YEUNG, E. C.; THORPE, T. A. (1985) . Origin of adventitious shoots in excised radiata pine cotyledons cultured in vitro. Canadian Journal of Botany, Ottawa, v. 63, n. 12, p. 2172-2176, Dec.

WITJAKSONO, R. E.; LITZ, R. E.;

PLIEGOALFARO, F. (1999). Somatic embryogenesis of avocado (Persea americana Mill.). In: JAIN,

S. M.; GUPTA P. K.; NEWTON, R. J. Somatic embryogenesis in woody plants. Dordrecht: Kluwer Academic Publishers, 1999. v. 5, p. 197-214. 